\title{
RENAL ANAEMIA: THE ROLE OF HAEMOGLOBIN CONTROL IN PATIENTS WITH CHRONIC KIDNEY DISEASE
}

\author{
Viktorija Kuzema ${ }^{\star, \star *}$, Aivars Pētersons ${ }^{\star, \star \star}$, Harijs Čerṇevskis ${ }^{\star, \star \star}$, and Aivars Lejnieks ${ }^{\star, \star \star \star}$ \\ * Rīga Stradinš̌ University, Dzirciema iela 16, Rīga, LV-1007, LATVIA; E-mail: viktorija.kuzema@gmail.com \\ ** Pauls Stradiṇš Clinical University Hospital, Rīga, Pilsoṇu iela 13, LV-1002, LATVIA \\ * Rīga Eastern Hospital, Hospital "Linezers", Rīga, LV-1006, LATVIA
}

Communicated by Igors Aksiks

\begin{abstract}
Chronic kidney disease (CKD) is a significant and prevalent health problem in the world. Anaemia is one of the most common manifestations in patients with CKD. The correction of anaemia with erythropoietin normalises haemoglobin level and improves quality of life. Many aspects of the impact of anaemia treatment with erythropoiesis-stimulating agents on the progression of CKD remain unresolved and disputable. The present study is a retrospective chart review of 1654 outpatients with CKD. The data were collected from the Centre of Nephrology between 1 January 2002 and 31 December 2006. The aims of the study were to assess the causes of CKD; the prevalence of anaemia based on the current guidelines for anaemia management in CKD (Kidney Disease Dialysis Outcomes Quality Initiative; K/DOQI); to evaluate haemoglobin (Hb), systolic and diastolic blood pressure (SBP and DBP), glomerular filtration rate (GFR) at the first referral to a nephrologist and at the start of renal replacement therapy (RRT). The most common causes of CKD were arterial hypertension (17.2\%), chronic glomerulonephritis (17.2\%), chronic intersticial nephritis (13.3\%), and diabetes (12.8\%). Twenty-three percent of end-stage renal disease (ESRD) patients had diabetes mellitus. At the first visit in the renal department, $16 \%$ of the patients had an advanced degree of CKD (GFR $<30 \mathrm{ml} / \mathrm{min}$ ). The proportion of patients under an observation in the kidney centre for a period of six months and more was only 34\% (554 of 1654). Hypertension was recorded in $72 \%$ of study subjects. The blood pressure (BP) values in patients at the first visit $(n=1633)$ vs. at the start of RRT $(n=154)$ were: mean SBP $147.4 \pm 24.8 \mathrm{~mm} \mathrm{Hg}$ vs. $152.2 \pm 23.0 \mathrm{~mm} \mathrm{Hg}(\mathrm{P}<0.05) ;$ mean $D B P 88.8 \pm 13.6 \mathrm{~mm} \mathrm{Hg}$ vs. $88.4 \pm 12.0 \mathrm{~mm} \mathrm{Hg}(P$ 0.05). Anaemia was recorded in $41 \%$ of study subjects, estimated using K/DOQI recommendations. The prevalence of anaemia was increased from $30.2 \%$ to $44.8 \%$ of study patients with a rise of $B P$ (from normal BP to hypertension; $\mathrm{P}<0.05$ ). The mean $\mathrm{Hb}$ level at the start of RRT was $9.8 \pm 2.1 \mathrm{~g} / \mathrm{dl}$. Only $18 \%$ of patients with renal anaemia had used erythropoiesis-stimulating agents before RRT (28 of 155). Anaemia is the prevalent condition at moderate degrees of CKD. The severity of anaemia in the CKD population is determined by evidence of diabetes, cardiovascular disease, and renal function. Anaemia may often be unrecognised or untreated.
\end{abstract}

Key words: chronic kidney disease, anaemia, erythropoietin.

\section{INTRODUCTION}

Chronic kidney disease (CKD) is a significant public health problem in the world and has a remarkable impact on cardiovascular morbidity and mortality in patients with endstage renal disease (ESRD) (Foley et al., 1998). In Latvia, there were estimated 58.7 (Locatelli et al., 2004) and 69.1 (Cannata-Andia et al., 2007) incident patients per million population with ESRD in 2002 and 2005, respectively. In addition, the prevalence of patients with renal replacement therapy (RRT) significantly rose during five years and accounted for 368.6 patients per million population in 2006 (London, 2008). Diabetic kidney disease is the leading cause of end-stage renal disease (ESRD) in USA and Europe (Ritz, 1999). In Latvia, 23\% of the ESRD patients have been reported to suffer from diabetes mellitus $(\mathrm{Ku}-$ zema et al., 2008). An important aspect in the management of CKD is to evaluate risk factors and underlying causes of development of chronic kidney damage (McClellan et al., 2003), which may be diabetes, hypertension, proteinuria, metabolic disorders and anaemia (Levin, 2001). The role of anaemia in CKD has received much attention of nephrologists. In addition, with the beginning of the erythropoietin era, the treatment of renal anaemia is considered as a significant in the possible delaying of progression of CKD (Rossert et al., 2002).

The aims of the study were: to assess the causes of CKD; to analyse the prevalence of anaemia based on the current guidelines for anaemia management in CKD (Kidney Dis- 
ease Dialysis Outcomes Quality Initiative; K/DOQI); to evaluate haemoglobin $(\mathrm{Hb})$, systolic and diastolic blood pressure (SBP and DBP), glomerular filtration rate (GFR) in patients at their first referral to a nephrologist and at the start of renal replacement therapy (RRT).

\section{PATIENTS AND METHODS}

The study is a retrospective analysis involving one centre and consists of data of 6520 consultations for CKD patients during five years (2002-2006). The data was collected from the archive of the Latvian Nephrology Centre. We studied the prevalence of causes of underlying renal disease, distribution of stages in $\mathrm{CKD}$, clinical and laboratory findings on the first visit in the kidney centre and at the start of RRT, and the prevalence of anaemia and hypertension in patients with CKD.

A total of 1654 patients were examined in the study. We selected the following parameters: the data of patient visit, gender, age, primary renal disease, outcome, systolic blood pressure (SBP), diastolic blood pressure (DBP), weight, presence of diabetes, use of erythropoiesis stimulating agents (ESA), serum creatinine, haemoglobin ( $\mathrm{Hb})$ level, and ferritin concentration. The outcomes of analysis were: RRT, including hemodialysis (HD), peritoneal dialysis (PD) and kidney transplantation (Tx); death; and continuation of observation for each person on 31 December 2006. Excluded were patients who had pregnancy, acute infection, systemic disease with active immunosuppressive therapy, malignancy including haematological malignances, single kidney, patients with previous or current RRT. The final data set contained 4134 consultations of subjects with CKD.

For the purpose of this study, we use the definitions for CKD, hypertension, anaemia as follows.

Classification and definition of chronic kidney disease. According to the ERA-EDTA kidney disease coding system, CKD was divided into eight groups (Fig. 1): I. Glomerulonephritis; II. Pyelonephritis; III. Polycystic kidney disease; IV. Hypertension; V. Renovascular disease; VI. Diabetes mellitus; VII. Miscellaneous (chronic interstitial nephritis, gout, lead nephropathy, occupational diseases, systemic disorders etc.); VIII. Unknown diseases.

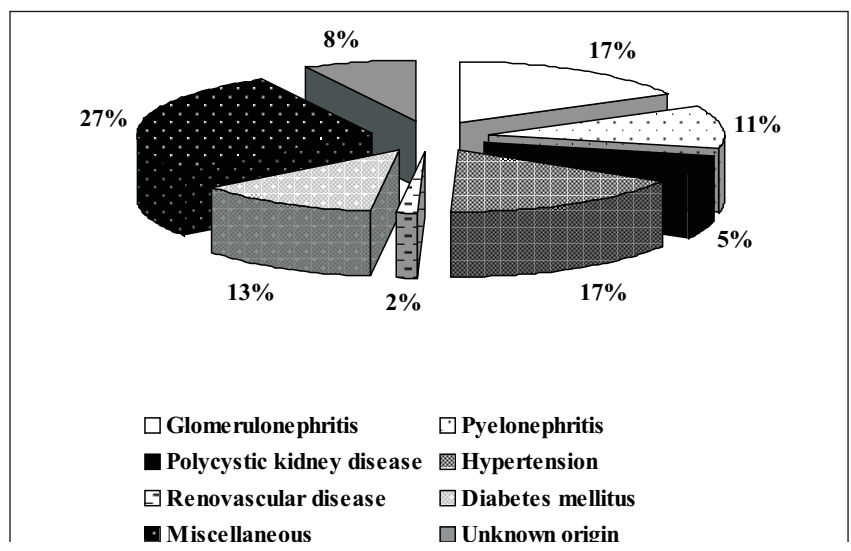

Fig. 1. The causes of chronic kidney disease (CKD) in the examined patients $(\mathrm{n}=1654)$.
GFR and CKD classification according to stages. Glomerular filtration rate (GFR) was calculated using the Cockcroft - Gault equation (Cockcroft and Gault, 1976):

GFR $(\mathrm{ml} / \mathrm{min})=[(140-$ age, years $) \times($ weight, $\mathrm{kg})] / 72 \times$ plasma creatinine, mg/dl. For women the result was multiplied by 0.85 .

According to GFR, CKD was divided in five sequential stages: stage I - GFR >90 ml/min; stage II - GFR 60-89 $\mathrm{ml} / \mathrm{min}$; stage III - GFR 30-59 $\mathrm{ml} / \mathrm{min}$; stage IV - GFR 15-29 $\mathrm{ml} / \mathrm{min}$; stage $\mathrm{V}-\mathrm{GFR}<15 \mathrm{ml} / \mathrm{min}$ or dialysis (Bolton et al., 2002).

Hypertension. The following definitions and classification were suggested by the seventh report of the Joint National Committee:

1. Normal blood pressure: systolic $<120 \mathrm{~mm} \mathrm{Hg}$ and diastolic $<80 \mathrm{~mm} \mathrm{Hg}$.

2. Pre-hypertension: systolic $120-139 \mathrm{~mm} \mathrm{Hg}$ or diastolic 80-89 mm Hg.

3. Hypertension: Stage 1: systolic $140-159 \mathrm{~mm} \mathrm{Hg}$ or diastolic 90-99 mm Hg; Stage 2: systolic $160 \mathrm{~mm} \mathrm{Hg}$ or diastolic $100 \mathrm{~mm} \mathrm{Hg}$ (Chobanian et al., 2003).

Anaemia. According to USA K/DOQI guidelines concerning anaemia treatment in CKD patients, anaemia diagnosis is credible when the $\mathrm{Hb}$ level is $<13.5 \mathrm{~g} / \mathrm{dl}$ in men and $<12.0 \mathrm{~g} / \mathrm{dl}$ in women (Adamson et al., 2006).

Iron status also was calculated. Because our study had a retrospective design and there was available only serum ferritin concentration, we formulated the following criteria of iron storage: adequate iron status was considered as serum ferritin concentration of $100 \mathrm{ng} / \mathrm{ml}$ and iron deficiency was considered as serum ferritin less then $100 \mathrm{ng} / \mathrm{ml}$. The data for transferrin saturation were not available and we did not have the possibility to check functional iron deficiency.

All examined patients were selected by gender and by age in following groups: $0-20 ; 21-44 ; 45-64$; $\geq 65$ years.

Statistical analysis. Statistical Package for the Social Sciences (SPSS) version 15.0 software was used for all analyses (SPSS Inc., Chicago, IL). Descriptive analyses are presented as mean with standard deviation or median with range, depending on the underlying distribution. We used $t$-tests, ANOVA for comparisons between parameters in independent groups. Pearson Chi-square or Mann-Whitney U tests were used to compare qualitative variables. The criterion for statistical significance was taken as a two-tailed $P$ value $<0.05$.

\section{RESULTS}

Epidemiology. The causes of CKD in the enrolled population were: hypertensive nephropathy $(n=284)$, chronic glomerulonephritis $(\mathrm{n}=284)$, intersticial nephritis $(\mathrm{n}=$ $220)$, diabetes mellitus $(n=211)$, pyelonephritis $(n=184)$, 
kidney disease of unknown origin $(n=127)$, polycystic kidney disease $(\mathrm{n}=82)$, systemic lupus erythematosus and vasculites $(n=45)$, renal hypoplasia congenital - type unspecified $(n=27)$, gout nephropathy $(n=27)$, renal vascular disease due to renal artery stenosis/occlusion $(n=25)$, nephropathy due to analgesic drugs $(\mathrm{n}=25)$, nephrocalcinosis $(n=23)$, hereditary nephropathy $(n=21)$, cystic kidney disease - other specified type $(\mathrm{n}=21)$, amyloid $(\mathrm{n}=$ $19)$, tubular necrosis $(n=8)$, tuberculosis $(n=6)$, other identified renal disorders $(n=6)$, medullary cystic disease $(n=4)$, lead induced nephropathy $(n=2)$, haemolytic uremic syndrome $(\mathrm{n}=1)$, sarcoidosis $(\mathrm{n}=1)$, and trauma $(\mathrm{n}=$ 1 ). Diabetes was one of the most common causes for endstage renal disease $(23 \%)$ followed by glomerulonephritis $(28 \%)$. Evidence of diabetes type 2 was observed in $44 \%$ (16 of 36) of ESRD patients. The mean age of patients was $55.9 \pm 17.1$ years $(n=1654)$. The proportion of women in the analysed population was significantly higher: $62.3 \%$ (total $\mathrm{n}=1654$ ). In addition, female patients were older than male: $57.5 \pm 16.1$ years in female and $54.1 \pm 18.3$ years in male $(P<0.001)$.

At the start of dialysis therapy mean age was $54.2 \pm 16.0$ (n $=155)$. Furthermore, $73.5 \%$ of them were part of the ablebodied population and $26.5 \%$ were above 65 years old. Forty-eight percent of patients were female (75 of 155). There was no significant difference in mean age between female and male patients with ESRD: 53.6 years versus 54.8 years $(P>0.05)$.

The majority of patients with different stages of CKD (840 of 1654) visited the Centre of Nephrology only once. The patients with repeated visits to a nephrologists had the following distributions of time under the observation: $8.1 \%$ (n $=67)$ for $<1$ month; $23.7 \%(\mathrm{n}=193)$ for 1 to 6 months; $17.2 \%(\mathrm{n}=140)$ for 6 to 12 months; $21.9 \%(\mathrm{n}=178)$ for 12 to 24 months; and $29 \%(\mathrm{n}=236)$ patients were under care of a nephrologist for over two years. The mean duration of the time under care of a nephrologist for patients who were observed repeatedly was 17.6 months, range from 1 to 59 months. Median period of time under care of a nephrologist for these patients was 13 months. At the visit to dialysis department, $14 \%$ (21 of 155) of the ESRD patients had visits for the first time. Thirteen patients were observed for one month; 22 patients for 1 to 6 months; 24 patients for 6 to 12 months; 38 patients for 12 to 24 months; 20 patients for $2-3$ years; and 17 patients over three years. The mean observation period before start of dialysis therapy for patients with repeated consultation was 17.4 months, ranged from 1 to 53 months. Median length of the time under care of a nephrologist for patients who were observed repeatedly before initiation of RRT was 15 months. Peritoneal dialysis was started for $50(32 \%)$ patients, haemodialysis for $103(67 \%)$ patients, and $2(1 \%)$ patients had preemptive kidney transplantations.

At the time of first referral, 54\% (893 of 1653) of patients presented clinically impaired renal function (GFR $<60$ $\mathrm{ml} / \mathrm{min}$ ). The distribution of CKD for all patients at the first visit to a nephrologist was as follows (Table 1). By stage,
Table 1

DISTRIBUTION OF CHRONIC KIDNEY DISEASE (CKD) FOR ALL EXAMINED PATIENTS AT THE FIRST VISIT

\begin{tabular}{c|c|c}
\hline Stage & GFR $(\mathrm{ml} / \mathrm{min})$ & Patients, $\mathrm{n}(\%)$ \\
\hline I & $\geq 90$ & $311(18.8)$ \\
II & $60-89$ & $441(27.2)$ \\
III & $30-59$ & $622(37.6)$ \\
IV & $15-29$ & $227(13.7)$ \\
V & $<15$ or dialysis & $44(2.7)$
\end{tabular}

GFR, glomerular filtration rate.

an estimated 311 subjects (18.8\%) had stage I; $441(27.2 \%)$ stage II; 622 (37.6\%) stage III; 227 (13.7\%) stage IV; and $44(2.7 \%)$ had end-stage renal disease. At the start of RRT (haemodialysis or peritoneal dialysis) GFR ranged from 3.5 $\mathrm{ml} / \mathrm{min}$ to $29.8 \mathrm{ml} / \mathrm{min}$. Mean GFR and standard deviation was $12.9 \pm 5.1 \mathrm{ml} / \mathrm{min}$. In addition, 33\% (47 of 144) of these patients had glomerular filtration rate above 15 $\mathrm{ml} / \mathrm{min}$. Unfortunately, we lacked information on some clinical details for starting dialysis therapy because the study had a retrospective design.

Hypertension. Hypertension was the prevalent condition in patients with CKD (Fig. 2). At a patient first visit to a nephrologist normal blood pressure was estimated only in $5.8 \%$ (96 of 1654). Pre-hypertension and hypertension were recorded in $22.1 \%$ (365 of 1654) and $72.1 \%$ (1192 of 1654) of patients, respectively. In addition, subjects with hypertension stage 1 and stage 2 were recorded in $29.1 \%$ and $43.0 \%$, of cases, respectively. At the start of dialysis therapy systolic blood pressure was significantly higher compared with patients without RRT: $152.2 \pm 23.0 \mathrm{~mm} \mathrm{Hg} v s$. $147.4 \pm 24.8 \mathrm{~mm} \mathrm{Hg}(P<0.05)$. No difference in the diastolic blood pressure record was found across CKD patients (with or without RRT) $(P>0.05)$.

Anaemia. At the first visit to Centre of Nephrology, haemoglobin level was determined in $72 \%$ of patients with CKD (1179 of 1633 patients). Haemoglobin level ranged from $6.3 \mathrm{~g} / \mathrm{dl}$ to $18.1 \mathrm{~g} / \mathrm{dl}$, with a mean and standard deviation of $12.7 \pm 2.0 \mathrm{~g} / \mathrm{dl}$ (Fig. 3). Median haemoglobin level for these study patients was $13 \mathrm{~g} / \mathrm{dl}$. Baseline haemoglobin levels for 143 patients with RRT (92\%; total $\mathrm{n}=155$ patients) are illustrated in Figure 4. There was missing data

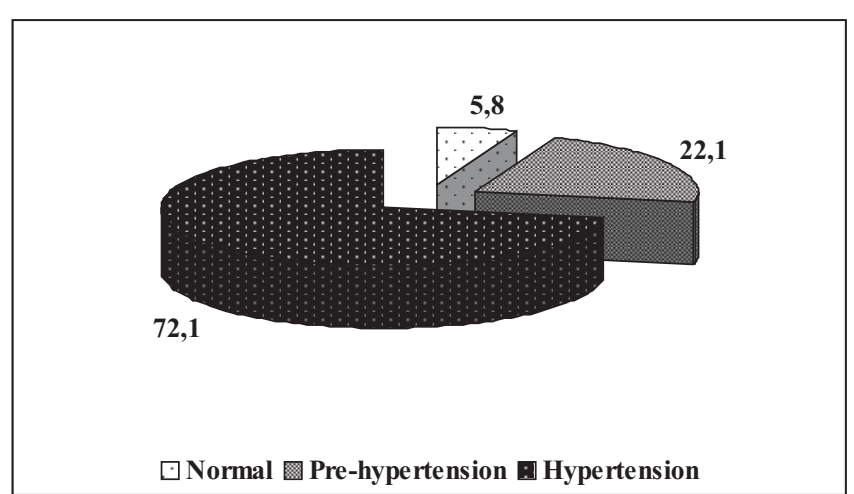

Fig. 2. Prevalence of hypertension in patients with chronic kidney disease (CKD), \% (n=1654). 


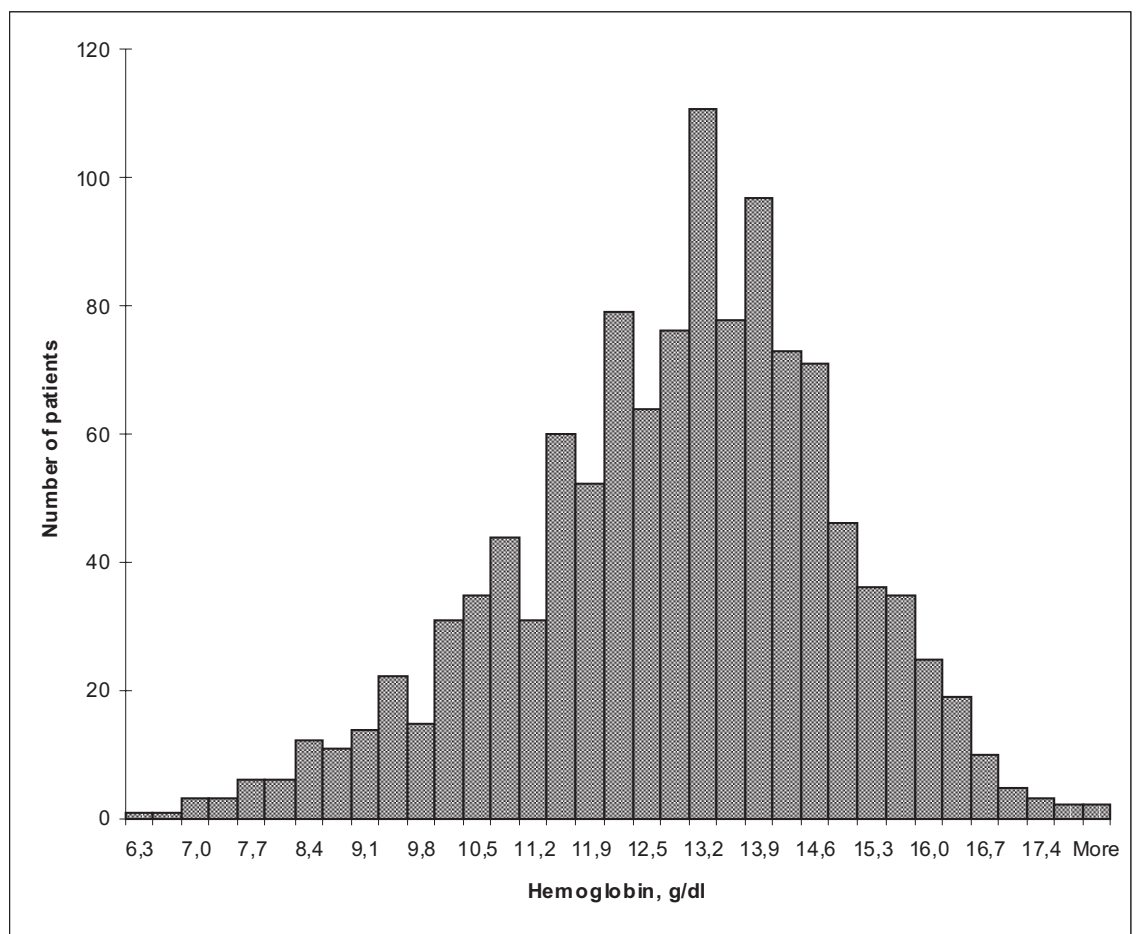

Fig. 3. Distribution of haemoglobin level in patients with chronic kidney disease (CKD) before renal replacement therapy $(\mathrm{RRT})(\mathrm{n}=1179)$. for haemoglobin level in 12 patients with RRT. Haemoglobin level ranged from $5.1 \mathrm{~g} / \mathrm{dl}$ to $14.6 \mathrm{~g} / \mathrm{dl}$, with a mean and standard deviation of $9.8 \pm 2.1 \mathrm{~g} / \mathrm{dl}$. Median haemoglobin level for ESRD patients was $9.6 \mathrm{~g} / \mathrm{dl}$.

Evidence of anaemia was estimated at the first visit in kidney centre for all patients, including patients with RRT (total $n=1644)$. Patients with erythropoietin therapy were excluded. At the first visit to a nephrologist there was missing data for serum haemoglobin level in 455 patients (28\%, total number $=1644)$. Forty one percent of patients $(n=487)$ had been diagnosed as anaemic using K/DOQI recommendations.

The study results demonstrated that with progression of CKD haemoglobin concentration considerably decreased.

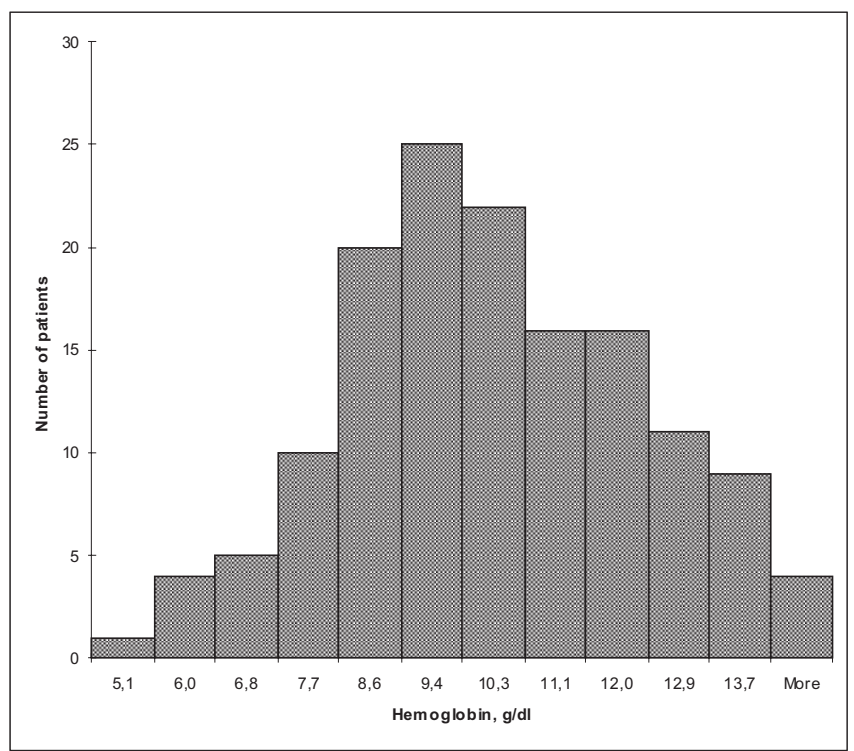

Fig. 4. Distribution of haemoglobin level in patients with renal replacement therapy $(\mathrm{RRT})(\mathrm{n}=143)$.
Figure 5 shows decrease of haemoglobin level in diabetic and non-diabetic kidney diseases $(P<0.001)$. Mean haemoglobin levels for diabetic versus non-diabetic patients were $13.5 \pm 1.6 \mathrm{~g} / \mathrm{dl} v s .14 .1 \pm 1.6 \mathrm{~g} / \mathrm{dl} ; 13.2 \pm 1.5 \mathrm{~g} / \mathrm{dl} v s$. $13.5 \pm 1.5 \mathrm{~g} / \mathrm{dl} ; 12.4 \pm 1.8 \mathrm{~g} / \mathrm{dl}$ vs. $13.0 \pm 1.7 \mathrm{~g} / \mathrm{dl} ; 10.3 \pm$ $1.5 \mathrm{~g} / \mathrm{dl} v s .11 .2 \pm 1.9 \mathrm{~g} / \mathrm{dl} ; 9.4 \pm 1.5 \mathrm{~g} / \mathrm{dl} v s .9 .4 \pm 1.9 \mathrm{~g} / \mathrm{dl}$ in stage I, II, III, IV, V CKD, respectively (Fig. 5).

The association between blood pressure and the prevalence of anaemia estimated by K/DOQI are presented on Figure 6. Haemoglobin concentration data was missing in 485 patients. The percentage anaemic patients with CKD was progressively higher with increased arterial blood pressure (Pearson Chi-square test; $P<0.05$ ).

Serum ferritin level in subjects with GFR $<\mathrm{ml} / \mathrm{min}$ was checked in only $13 \%$ of cases. Serum ferritin ranged from $1.1 \mathrm{ng} / \mathrm{ml}$ to $1196 \mathrm{ng} / \mathrm{ml}$. Median serum ferritin level for these study patients was $121 \mathrm{ng} / \mathrm{ml}$.

Only $18 \%$ of patients with renal anaemia had used erythropoiesis-stimulating agents before RRT (28 of 155).

\section{DISCUSSION}

This is the first study in Latvia on CKD patients observed during a five-year period. We found that the most common causes of chronic kidney disease were arterial hypertension (17.2\%), chronic glomerulonephritis (17.2\%), chronic intersticial nephritis (13.3\%), and diabetes (12.8\%). Moreover, the proportion of patients with diabetes as the primary cause of ESRD in Latvia was $23 \%$. Diabetes is the leading cause of CKD developing countries. High prevalence and incidence of diabetic kidney disease in the CKD population has been reported in previous publications (Zimmet et al., 2001). The incidence rate of ESRD due to diabetes in the 

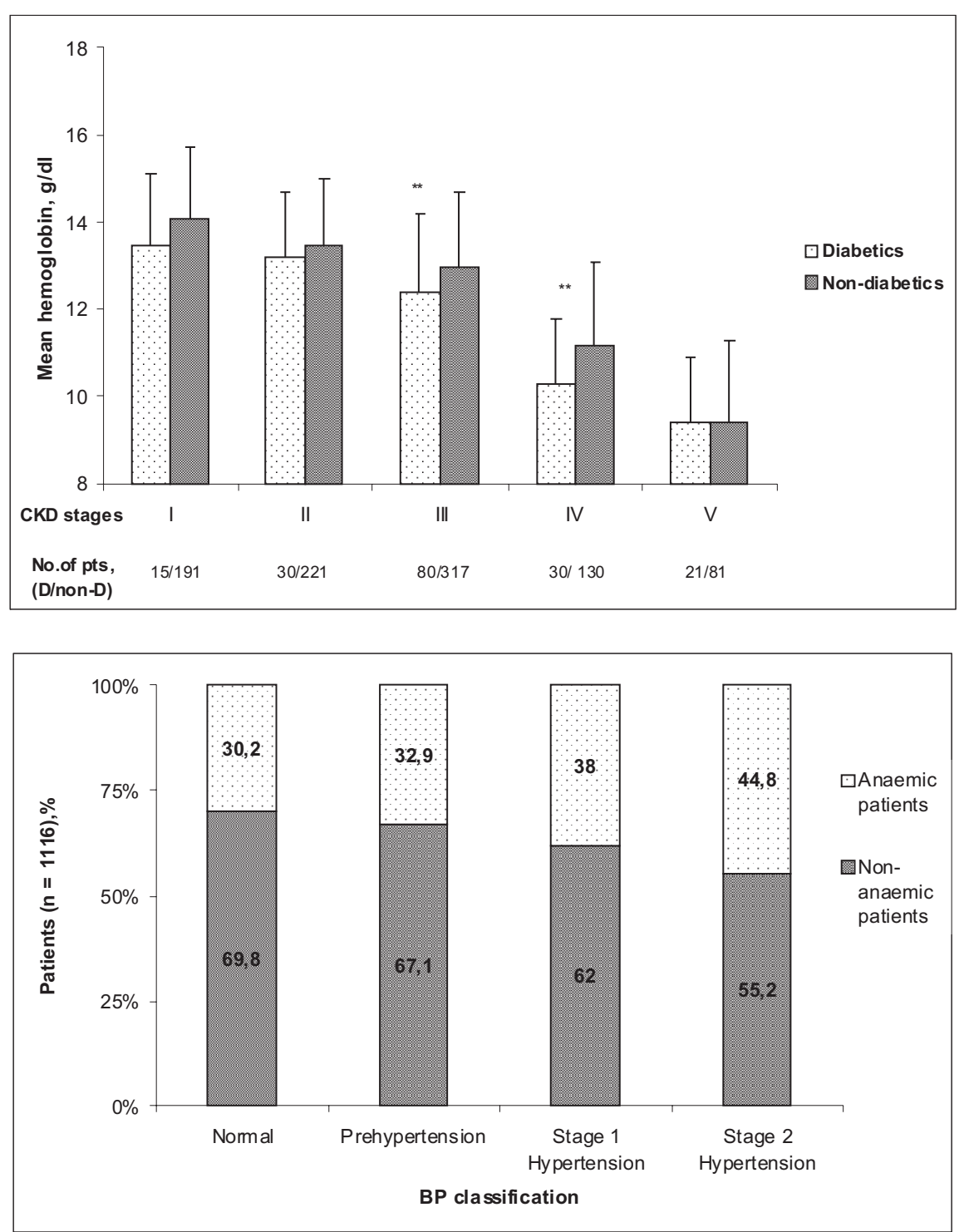

Fig. 5. Haemoglobin level in diabetic versus non-diabetic patients by chronic kidney disease (CKD) stage; pts, patients; D, diabetics; non-D, non-diabetics; $* * P<0.05$.
Fig. 6. Prevalence of anaemia depending on blood pressure (BP).
United States has recently stabilised, however, it had grown by nearly $60 \%$ and the rate per million population in 2005 remained at 152 (Collins et al., 2007).

The mean age of patients at the start of RRT in our study was 54.2 years. PRESAM results showed that the mean age of incident dialysis patients was 59.1 years (Valderribano et al., 2003). The USRDS data demonstrated an estimated mean age of 62.7 years in incident ESRD patients (Collins et al., 2007). The possible factors for this difference may be insufficient control and diagnostics of chronic kidney disease before dialysis treatment in Latvia. Secondly, the mean age of incident ESRD patients performed by USRDS was based on the general population, while our results reflect data from a single centre.

Most of the patients $(16 \%)$ presented as a late referral to a renal centre (GFR $<30 \mathrm{ml} / \mathrm{min}$ ). Fifty four percent of all analysed patients at first visit to a nephrologist had GFR below $60 \mathrm{ml} / \mathrm{min}$. About a half of all patients (50.8\%) were in a kidney centre only once. The patients with duration of the time under care of a nephrologist at least six months and over were $33.5 \%$ : $8.5 \%$ for 6 to 12 months; $10.8 \%$ for 12 to 24 months; $6.8 \%$ for two to three years; and $7.4 \%$ for three and over years. In addition, at the first visit to dialysis department, $14 \%$ (21 of 155) of patients started RRT immediately. This finding shows that, at first, most of the patients present to the renal department with advanced degrees of CKD. Secondly, only one-third of the patients were under care of nephrologists for over six months. Similar data have been published elsewhere. Hörl et al. summarised data of a major retrospective study PRESAM (PREdialysis Survey on Anaemia Management) covering information on 4333 CKD patients from 23 countries, published in 2003, and made several practical conclusions. One of the most common problems was late nephrologist referral for patients with progressing renal failure, which once again made poor condition of renoprotective and cardioprotective treatment strategies an issue as patients enter nephrology centre late: average GFR at first visit was $18.2 \mathrm{ml} / \mathrm{min}$ (Hörl et al., 2003).

Hypertension was a prevalent condition in patients with CKD in our study patients. Hypertension was recorded in $72 \%$ of the patients. Hörl et al. (2003) presented 78\% patients with CKD and hypertension. This report is distinctive since a different classification of blood pressure was used. 
We used the classification of blood pressure suggested by the $7^{\text {th }}$ report of the JNC and hypertension was defined as systolic blood pressure above $140 \mathrm{~mm} \mathrm{Hg}$ or diastolic above $90 \mathrm{~mm} \mathrm{Hg}$, while PRESAM study researchers defined hypertension as the blood pressure above 145/95 mm $\mathrm{Hg}$ (Hörl et al., 2003). In our study, the prevalence of anaemia was significantly associated with a rise of arterial blood pressure. In a retrospective study by Phillipp et al. (2005), logistic regression was performed to evaluate the relative risk for several variables, including hypertension, on anaemia in 2941 patients with CKD. They found that arterial hypertension itself had no influence on anaemia, since diabetes was an independent risk factor on haemoglobin level and had an relative risk of $1.8(95 \% \mathrm{CI} ; 1.28-2.54 ; P<0.05)$ (Phillipp et al., 2005). However, the left ventricular hypertrophy and heart failure as the consequences of chronic arterial hypertension and its relationship with the anaemia in predialysis patients is clearly considered in numerous studies (Foley et al., 1998; Levin et al., 1999; Jurkovitz et al., 2003; Phillipp et al., 2005; Vlagopoulos et al., 2005; Drüeke et al., 2006).

Anaemia is one of the most common manifestations in CKD patients. The results of the retrospective analysis of this study suggest that anaemia among patients with stages I - V CKD is very common. According to USA guidelines on anaemia diagnostics, anaemia in CKD patients $(\mathrm{Hb}$ $<13.5 \mathrm{~g} / \mathrm{dl}$ in men and $<12.0 \mathrm{~g} / \mathrm{dl}$ in women) was diagnosed $41 \%$ of patients $(n=487)$. The mean haemoglobin level of patients at the start of RRT in our study was $9.8 \mathrm{~g} / \mathrm{dl}$, which is similar with that in the PRESAM report, estimated as below $10 \mathrm{~g} / \mathrm{dl}$ (Hörl, 2003). The Levin et al. study results show than mean haemoglobin in patients with GFR $<15$ $\mathrm{ml} / \mathrm{min}$ was $9.9 \mathrm{~g} / \mathrm{dl}$ (Levin et al., 2006). Only $18 \%$ of patients with renal anaemia had used erythropoietin prior to RRT. However, despite the high prevalence of anaemia in CKD patients, haemoglobin level was not determined in $28 \%$ of subjects. This obviously reveals indicates lack of information concerning CKD in the context of primary medical care. Clinical manifestations of anaemia emerge if the haemoglobin level falls to $<11 \mathrm{~g} / \mathrm{dl}$, which is the reason why erythropoietin therapy and iron supplementation is recommended during this period according to main guidelines. However, as demonstrated in our study by a low proportion of patients undergoing anaemia treatment with erythropoietin, primary care physicians may not be aware of the critical importance of screening for anaemia in the CKD population and anaemia may often be unrecognised or untreated.

The association between impaired renal function, anaemia and diabetes is well recognised in several studies (Bosman et al., 2001; El-Achkar et al., 2005; Ravanan et al., 2007). Anaemia in diabetic nephropathy is more severe than seen in patients with non-diabetic kidney disease. Several studies have suggested that anaemia occurs at an earlier stage of the disease and is more severe in patients with diabetic nephropathy than in non-diabetic kidney disease patients. Ravanan et al. (2007) reported that mean haemoglobin levels in diabetic patients compared with those in non-diabetics were 129.5 vs. $136.9 \mathrm{~g} / \mathrm{l}(P<0.01), 120.5$ vs. $126.9 \mathrm{~g} / \mathrm{l}(P<$
$0.01)$ and 107.1 vs. $115.9 \mathrm{~g} / \mathrm{l}(P<0.01)$ at stages III, IV and V CKD, respectively (Ravanan et al., 2007). Bosman et al. (2001) compared 27 patients with diabetic nephropathy with 26 non-diabetic patients with glomerulonephritis and demonstrated that anaemia was presented in 13 of the 27 diabetics (mean $\mathrm{Hb} 10.6 \pm 0.9 \mathrm{~g} / \mathrm{dl}$ ), in marked contrast to non-diabetics (mean $\mathrm{Hb} 13.7 \pm 0.9 \mathrm{~g} / \mathrm{dl} ; P<0.05$ ) (Bosman et al., 2001). The result of our study is similar. We show that the diabetic nephropathy in patients with stage III $-\mathrm{V}$ $\mathrm{CKD}$ is associated with more severe anaemia than non-diabetic patients $(P<0.001)$.

The main limitations of our study are the retrospective analysis design and missed factors to control. Therefore, the completed data for several variables, including erythropoietin therapy regimen, usage of iron, comorbidities (cardiovascular diseases, excluding hypertension) with its treatment possibilities, and other clinical significant manifestations in patients with CKD (secondary hyperparathyreoidism, malnutrition, dislipidemia) were not available, and maybe, can impact on our study derived results. However, despite this study weakness, we can conclude that anaemia is commonly observed among subjects with stage III -V CKD and more often in diabetics. Diabetic kidney disease is associated with lower haemoglobin levels in comparison with non-diabetic kidney disease. Despite the high prevalence of anaemia in the examined patients, erythropoietin therapy is underused. We hope that this finding may result in multidisciplinary healthcare team doctors to regularly monitor haemoglobin level and provide timely treatment with erythropoietin and iron supplementations.

\section{ACKNOWLEDGMENTS}

We thank the following persons who participated in data collection in the archive of Latvian Nephrology Centre: Ilze Puide, MD; Dzintra Krugale, MD; Inese Mihailova, MD, PhD ; Zane Smeltere, MD; Vita Faustmane, and Jana Riza.

\section{REFERENCES}

Adamson, J.W., Bailie, G.R., Berns, J.S., Eckardt, K.U., Fishbane, S., Foley, R.N., Ghaddor, S., Gill, J.S., Jabs, K., Locatelli, F., Macdougall, I.C., McCarley, P.B., Messner, H.H., Nissenson, A.R., Obrador, G.T., Stilman, J.C., Van Wyck, D.B., White, C.T. (2006). NKF-DOQI guidelines. Clinical Practice Guidelines and Clinical Practice Recommendations for Anemia in Chronic Kidney Disease in Adults. Identifying Patients and Initiating Evaluation. Amer. J. Kidney Dis., 5(3), 17-27.

Bolton, K., Coush, J., Culleton, B., Harvey, K.S., Ikizler, T.A., Jonson, C.A., Kausz, A., Kimmel, P.C., Kusek, J., Levey, A.S., Levin, A., Minaker, K.L., Nelson, R., Rennke, H., Steffes, M., Witten, B., Furth, S., Hogg, R.J., Lemley, K.V., Portman, R.J., Schwartz, G.J. (2002). NKF K/DOQI Clinical Practice Guidelines for Chronic Kidney Disease: Evaluation, classification, and stratification. Amer. J. Kidney Dis., 39(1), 14-17.

Bosman, D.R., Winkler, A.S., Marsden, J.T., Macdougall, I.C., Watkins, P.J. (2001). Anemia with erythropoietin deficiency occurs early in diabetic nephropathy. Diabetes Care, 24, 495-499.

Cannata-Andia, J., Zoccali, C., Wanner, C., Ansell, D., Combe, C., Lopez, F.G., Kramar, R., Leivestad, T., Macleod, A., Tizard, J., Verrina, E. (2007). ERA-EDTA Registry: ERA-EDTA Registry 2005 Annual Report. Amsterdam: Academic Medical Center, Department of Medical Informatics, pp. $86,108$. 
Chobanian, A.V., Bakris, G.L., Black, H.R., Cushman, W.C., Green, L.A., Izzo J.L., Jones, D.W., Materson, B.J., Oparil, S., Wright, J.T., Roccello, E.J., and the National High Blood Pressure Education Program Coordinating Committee. (2003). The Seventh Report of the Joint National Committee on Prevention, Detection, Evaluation, and Treatment of High Blood Pressure. NIH publication No. 03-5233, pp. 2-3.

Cockcroft, D.W., Gault, M.H. (1976). Prediction of creatinine clearance from serum creatinine. Nephron, 16, 31-41.

Collins, A., Foley, R., Chavers, B., Gilbertson, D., Herzog, C., Kasiske, B., Mau, L.W., Murray, A., St. Peter, W., Xue, J. (2007). United States Renal Data System. USRD Annual Data Report: Atlas of Chronic Kidney Disease and End-Stage Renal Disease in the United States. National Institutes of Health, National Institute of Diabetes and Digestive and Kidney Disease, pp. 84-85.

Drüeke, T.B., Locatelli, F., Clyne, N., Eckardt, K.U., Macdougall, I.C., Tsakiris, D., Burger, H.U., Scherhag, A. (2006). Normalization of hemoglobin level in patients with chronic kidney disease and anemia. New Engl. J. Med., 355, 2071-2084.

El-Achkar, T.M., Ohmitt, S.E., McCollough, P.A., Crook, E.D., Brown, W.W., Grimm, R., Bakris, G.L., Keane, W.F., Flack, J.M. (2005). Higher prevalence of anemia with diabetes mellitus in moderate renal insufficiency: The Kidney Early Evaluation Program. Kidney Int., 67, 1483-1488.

Foley, R.N., Parfrey, P.S., Samak, M.J. (1998). Clinical epidemiology of cardiovascular disease in chronic renal disease. Amer. J. Kidney Dis., 32(3), 112-119.

Hörl, W.H., Macdougall, I.C., Rosset, J., Rutkowski, B., Wauters, J.P., Valderrábano, F. (2003). Pre-dialysis survey on anaemia management: Patient referral. Amer. J. Kidney Dis., 1, 49-61.

Jurkovitz, C.T., Abramson, J.L., Vaccarino, L.V., Weintraub, W.S., McClellan, W.M. (2003). Association of high serum creatinine and anaemia increases the risk of coronary events: Results from prospective community-based atherosclerosis risk in communities (ARIC) study. J. Amer. Soc. Nephrol., 14, 2919-2925.

Kuzema, V., Petersons, A., Lejnieks, A. (2008). Influence of diabetic kidney disease on hemoglobin level. Grām.: 2008. gada Zinātniskās konferences tēzes. Rīga: RSU, 98. lpp.

Levin, A. (2001). Identification of patients and risk factor in chronic kidney disease - evaluating risk factor and therapeutic strategies. Nephrol. Dial. Transplant., 16(7), 57-60.
Levin, A., Djurdjev, O., Duncan, J. Rosenbaum, D., Werb, R. (2006). Haemoglobin at time of referral prior dialysis predicts survival: An association of haemoglobin with long-term outcomes. Nephrol. Dial. Transplant., 21, 915-919.

Levin, A., Thompson, C.R., Ethier, J., Carlisle, E.J.F., Tobe, S., Mendelssohn, D., Burgess, E., Jindal, K., Barrett, B., Singer, J., Djurdjev, O. (1999). Left ventricular mass index increase in early renal disease: Impact of decline in hemoglobin. Amer. J. Kidney Dis., 34, 125-134.

Locatelli, F., Zoccali, C., Wanner, C., Colosanti, G., Lopez, F.G., van der Heijden, A.J., Kramar, R., Leivestad, T., Macleod, A., Stengel, B., Tizard, J. (2004). ERA-EDTA Registry: ERA-EDTA Registry 2002 Annual Report. Amsterdam: Academic Medical Center, Department of Medical Informatics, p. 87.

London, G.M., Zoccali, C., Wanner, C., Ansell, D., Combe, C., Lopez, F.G., Kramar, R., Leivestad, T., Macleod, A., Tizard, J., Verrina, E. (2008). ERA-EDTA Registry: ERA-EDTA Registry 2006 Annual Report. Amsterdam: Academic Medical Center, Department of Medical Informatics, p. 95.

McClellan, W.M., Flander, W.D. (2003). Risk factor for progressive chronic kidney disease. J. Amer. Soc. Nephrol., 14, 65-70.

Phillipp, S., Ollmann, H., Schink, T., Dietz, R., Luft, F.C., Willenbrock, R. (2005). The impact of anaemia and kidney function in congestive heart failure and preserved systolic function. Nephrol. Dial. Transplant., 20, 915-919.

Ravanan, R., Spiro, J.R., Mathieson, P.W., Smith, R.M. (2007). Impact of diabetes of haemoglobin levels in renal disease. Diabetologia, 50, 26-31.

Ritz, E., Rychlik, I., Locatelli, F., Halimi, S. (1999). End stage renal failure in type 2 diabetes: A medical catastrophe of worldwide dimensions. Amer. J. Kidney Dis., 34, 795-808.

Rossert, J.A., McClellan, W.M., Roger, S,D, Verbeelen, D.L., Hörl, W.H. (2002). Contribution of anaemia to progression of renal disease; a debate. Nephrol. Dial. Transplant., 17(1), 60-66.

Valderrábano, F., Hörl, W.H., Macdougall, I.C., Rosset, J., Rutkowski, B., Wauters, J.P. (2003). Pre-dialysis survey on anaemia management. Nephrol. Dial. Transplant., 1, 89-100.

Vlagopoulos, P.T., Tighiouart, H., Weiner, D.E., Griffith, J., Pettitt, D., Salem, D.N., Levey, A.S., Sarnak, M.J. (2005). Anemia as a risk factor for cardiovascular disease and all-cause mortality in diabetes: The impact of chronic kidney disease. J. Amer. Soc. Nephrol., 16, 3403-3410.

Zimmet, P., Alberti, K.G., Shaw, J. (2001). Global and societal implications of the diabetes epidemic. Nature, 414, 782-787.

Received 2 April 2009

\section{RENĀLĀ ANĒMIJA: HEMOGLOBĪNA LĪMENA NOTEIKŠANAS NOZĪME SLIMNIEKIEM AR HRONISKU NIERU SLIMĪBU}

Hroniska nieru slimība (HNS) ir nozīmīga sabiedrības veselības problēma pasaules mērogā. Anēmija ir viena no biežākām HNS izpausmēm. Anēmijas ārstēšana ar eritropoēzi veicinošiem medikamentiem labvēlīgi ietekmē HNS attīstību, slimnieka dzīves kvalitāti un sirds un asinsvadu sistēmu. Darbā ir retrospektīvi analizēti 1654 slimnieki ar HNS (P. Stradiṇa Klīniskās universitātes slimnīcas Nefroloǵijas centra arhīva materiāli no 2002. līdz 2006. gadam). Pētījuma mērkis bija izpētīt HNS pamatcēloṇus, HNS slimnieku novērošanas ilgumu, arteriālās hipertensijas biežumu, anēmijas biežumu, smagumu un ārstēšanas iespējas slimniekiem ar HNS. Saskaṇā ar ASV vadlīnijām par anēmijas ārstēšanu HNS slimniekiem (KDOQI 2006) anēmijas diagnoze bija ticama, ja hemoglobīna (Hb) līmenis bija $<13,5 \mathrm{~g} / \mathrm{dl}$ vīriešiem un $<12,0 \mathrm{~g} / \mathrm{dl}$ sievietēm. Pētījuma rezultāti liecina, ka visbiežākie HNS cēloṇi bija hipertensīvā nefropātija (17,2\%), hronisks glomerulonefrīts $(17,2 \%)$, hronisks intersticiāls nefrīts $(13,3 \%)$, cukura diabēts $(12,8 \%)$. Bez tam cukura diabēts kā terminālas nieru mazspējas cēlonis bija 23\% slimnieku ar nieru aizstājterapiju (NAT). Pirmā vizītē 16\% slimniekiem tika konstatēta progresējoša nieru slimība (glomerulu filtrācijas ātrums $<30 \mathrm{ml} / \mathrm{min}$ ). Pētījuma rezultāti liecina, ka tikai 34\% (554 no 1654) analizēto slimnieku bija regulāra ilglaika (>6 mēneši) ambulatoriskā novērošana pie nefrologa. Arteriālā hipertensija tika konstatēta 72\% dalībnieku. Vidējais asinsspiediens pētījuma slimniekiem pirmajā vizītē $(n=1633)$ vs. NAT sākšanas brīdī $(n=154)$ bija šāds: vidējais sistoliskais asinsspiediens $($ SAS $)$ $147,4 \pm 24,8 \mathrm{~mm} \mathrm{Hg}$ vs. $152,2 \pm 23,0 \mathrm{~mm} \mathrm{Hg}$ ( $\mathrm{p}<0,05$ ); vidējais diastoliskais asinsspiediens (DAS) $-88,8 \pm 13,6 \mathrm{~mm} \mathrm{Hg}$ vs. 88,4 $\pm 12,0$ mm Hg (p >0.05). Saskan̄ā ar ASV rekomendācijām par anēmijas diagnostiku un ārstēšanu, anēmija tika konstatēta $41 \%$ analizēto slimnieku. Anēmijas biežums korelē ar arteriālo hipertensiju: no 30,2\% slimniekiem ar normālu arteriālo asinsspiedienu līdz 44,8\% dalībniekiem ar hipertensijas 2. pakāpi $(P<0,05)$. Vidējais Hb līmenis, sākot NAT, bija 9,8 $\pm 2,1 \mathrm{~g} / \mathrm{dl}$. Vidējais Hb līmenis slimniekiem ar cukura diabētu bija ticami zemāks nekā slimniekiem ar citu HNS pamatpatoloğiju. Eritropoetīnterapijas lietošana pirmsdialīzes periodā tika konstatēta tikai 18\% HNS slimnieku ar anēmiju. Anēmija ir viena no biežākām HNS klīniskām izpausmēm HNS slimniekiem. Anēmijas biežumu un smagumu nosaka blakus slimības (piem., cukura diabēts, sirds asinsvadu sistēmas slimības) un nieru funkcija (HNS stadija). Anēmija bieži vien netiek diagnosticēta un ārstēta. 